\title{
First species of Atomaria (Coleoptera: Clavicornia: Cryptophagidae) from Bitterfeld amber and several notes on Miocene and Cretaceous Cryptophagidae
}

\section{Первый вид Atomaria (Coleoptera: Clavicornia: Cryptophagidae) из саксонского янтаря и некоторые заметки о миоџеновых и меловых Cryptophagidae}

\author{
G.Yu. Lyubarsky ${ }^{1}$, E.E. Perkovsky ${ }^{2}$ \\ Г.Ю. Аюбарский, Е.Э. Перковский
}

\footnotetext{
Zoological Museum of Moscow State University, Bol'shaya Nikitskaya str. 2, Moscow, 103009 Russia. E-mail: lgeorgy@rambler.ru

1 Зоологический музей МГУ, ул. Б. Никитская 2, Москва 103009, Россия.

${ }^{2}$ Schmalhausen Institute of Zoology, Bogdan Khmelnitski str. 15, Kiev, 01601 Ukraine. E-mail: perkovsk@gmail.com
}

KEYWORDS. Atomariinae, Shixitomaria, Elytrophagus, Plastophagus, Late Eocene, Shixi Formation.

КЛЮЧЕВЫЕ СЛОВА. Atomariinae, Shixitomaria, Elytrophagus, Plastophagus, поздний эоцен, свита Шиси.

ABSTRACT. Atomaria saxonica Lyubarsky et Perkovsky sp.n., a first cryptophagid species from Bitterfeld amber, is described. The new species is the third described Eocene species of Atomariinae. The new species is similar to A. testacea Stephens, 1830 and $A$. analis Erichson, 1846. It differs from these species by the structure of antennae. The new species differs from other extinct Atomaria species in shape of pronotum, not narrowed towards base. Shixitomaria gen.n. is established for Atomaria cretacea Cai et Wang, 2013 from the Early Cretaceous of China. Mesozoic fauna of Cryptophagidae consist of five extinct genera; in Cenozoic cryptophagid fauna extinct genera unknown. The genera from Miocene of Shandong, Elytrophagus Zhang, 1989 and Plastophagus Zhang, 1989, probably do not belong to Cryptophagidae.

РЕЗЮМЕ. Описан первый вид криптофагид из саксонского янтаря - Atomaria saxonica Lyubarsky et Perkovsky sp.n. Это третий описанный эоценовый представитель Atomariinae. Новый вид сходен с обычными палеарктическими видами A. testacea Stephens, 1830 и A. analis Erichson, 1846. От этих видов новый эоценовый вид отличается строением усиков. Новый вид отличается от других вымерших видов Atomaria формой переднеспинки, не суженной к основанию. Установлен род Shixitomaria gen.n. для Atomaria cretacea Cai et Wang, 2013 из раннего мела Китая. Мезозойская фауна Cryptophagidae coстоит из пяти вымерших родов; в кайнозойской фауне Cryptophagidae вымершие роды не найдены.
Роды Elytrophagus Zhang, 1989 и Plastophagus Zhang, 1989, описанные из миоцена Шаньдуна, вероятно, не относятся к Cryptophagidae.

\section{Introduction}

A study of the collection of Christel and Hans Werner Hoffeins (CCHH) revealed a new species of Cryptophagidae. The family Cryptophagidae includes about 600 described species of small beetles, belonging to 53 genera. Cryptophagidae are mainly free-living and mycophagous. The family Cryptophagidae contains two subfamilies: Cryptophaginae and Atomariinae [Leschen, 1996]. The subfamily Atomariinae contains three tribes: Atomariini, Cryptafricini and Hypocoprini. The subfamily can be diagnosed by short body, frons without tubercle, short prosternum in front of coxa, tibia with apical spines.

Representatives of Atomaria are found in all biogeographic realms [Leschen, 1996; Johnson et al., 2007]; 127 species are known from the Palaearctic Region [Johnson et al., 2007]. The genus is rarely recorded in the Late Eocene ambers; the first Baltic amber species was described a few years ago [Lyubarsky, Perkovsky, 2013].

Late Eocene Baltic amber is the world's best-known source of inclusions. A list of recorded cryptophagid genera (both Cryptophaginae and Atomariinae) was given in Lyubarsky \& Perkovsky [2010]. The present fossil represents the family Cryptophagidae and the

How to cite this article: Lyubarsky G.Yu., Perkovsky E.E. 2018. First species of Atomaria (Coleoptera: Clavicornia: Cryptophagidae) from Bitterfeld amber and several notes on Miocene and Cretaceous Cryptophagidae // Russian Entomol. J. Vol.27. No.4. P.381-385. doi: 10.15298/rusentj.27.4.05 
genus Atomaria, as follows from the tarsal formula 5-55 , tarsomeres not lobed, antennal club 3-segmented, and other relevant characters.

Two species of Atomaria have been described from Baltic amber: A. gedanicola Lyubarsky et Perkovsky, 2013, and A. groehni Perkovsky et Lyubarsky, 2014 [Lyubarsky, Perkovsky, 2013; Perkovsky, Lyubarsky, 2014]. A. gedanicola is similar to A. fuscipes (Gyllenhal, 1808). A. groehni is similar to A. pusilla (Paykull, 1798 ) and A. morio Kolenati, 1846.

Silken fungus beetles from other Late Eocene ambers are less studied: from Rovno amber were described three cryptophagine species [Lyubarsky, Perkovsky, 2010, 2011, 2012], from other faunas no species were named [Bukejs et al., 2016]. In the present paper we describe a new species of Atomaria from Bitterfeld amber.

Photographs were taken at the Schmalhausen Institute of Zoology (Kiev, SIZK) using the microscope Leica MZ 16.

\section{Taxonomy}

Family Cryptophagidae Kirby, 1837

Subfamily Atomariinae LeConte, 1861

Genus Atomaria Stephens, 1829

Subgenus Anchicera Thomson, 1863

\section{Atomaria saxonica Lyubarsky et Perkovsky, sp.n. Figs 1-4.}

MATERIAL. Holotype: 1223-4, in collection of Christel and Hans Werner Hoffeins (Hamburg), Bitterfeld amber, Late Eocene. The type will be deposited at the amber collection of Senckenberg Deutsches Entomologisches Institut Müncheberg (SDEI), Germany. Collection code: $\mathrm{CCHH}$.

DESCRIPTION. Length of body $1.35 \mathrm{~mm}$, body elongate (Fig. 1), moderately arched, covered with slightly curved, decumbent pale pubescence of moderate length. Body, legs and antennae entirely dark brown.

Head transverse, finely punctured, distance between punctures greater than diameter of puncture; with hemispherical facetted eyes; length of eye 2 times less than length of head. Eye normally developed, with 14 facets in external margin of eye (when counted from dorsal view at the greatest length of the eye). Antennae short, slender, with club not reaching beyond base of pronotum (Fig. 2), joints of flagellum elongate, about 1.5 times as long as broad, antennomere 1 elongated, slightly curved, a little longer than $2^{\text {nd }}, 3-6^{\text {th }}$ a little shorter, 1.5 times as long as broad, antennomere $3^{\text {rd }}$ and $5^{\text {th }}$ longer than $4^{\text {th }}$ and $6^{\text {th }}, 7^{\text {th }}$ and $8^{\text {th }}$ slightly wider, antennomere $7^{\text {th }}$ narrower than $8^{\text {th }}, 9^{\text {th }}$ slightly transverse, narrower than $10^{\text {th }}, 10^{\text {th }}$ transverse, $11^{\text {th }}$ obliquely oval, joints $9-11$ equal in width, antennomere $11^{\text {th }}$ longer than $10^{\text {th }}$, slightly compressed. Antennae insertions widely separated basally.

Pronotum weakly transverse, of approximately same width from middle to base, 1.2 times as broad as long, weakly and finely punctured, distance between punctures equal to two puncture diameters. Anterior edge not sinuate, anterior angles without thickening or callosity. Sideborders visible from above only in the basal half. Base of pronotum with depression in the middle, with basal pits; hind angles rectangular; pronotal disk convex. Hind margin finely bordered, basal edge lobed. Prosternum finely punctured, distance between punctures greater than diameter of puncture (Fig. 3). Lines on the prosternal process absent, prosternal process not vaulted. Hind coxae set not far apart. Tarsal formula 5-5-5. Tibia slender, parallel-sided, with two spurs. Longitudinal metasternal line absent. Meta-intercoxal process wider than long. Femoral line absent. Ventrite 5 evenly arcuate; ventrite 5 without crenulations, surface unmodified.

Scutellum small, pentagonal, transverse. Elytra shortoval, moderately convex, humeral corners rounded, weakly curved at sides, maximum breadth of elytra in first third of their length, 2.1 times as long as pronotum, 1.2 times as long as broad (Fig. 4). Surface shining, moderately closely punctured, punctures in basal part slightly stronger than on pronotal disk, and approximately 1.0-1.5 diameters apart their lateral neighbours on an average. Elytral impression absent.

ETYMOLOGY. The species is named saxonica, because it was found in Bitterfeld amber (Saxony-Anhalt).

REMARKS. This species belongs to the subgenus $A n$ chicera and to the group of species with decumbent pubescence, pronotum not narrowed towards base, and transversal joints of club of antenna. The new species is similar to Atomaria analis Erichson, 1846 and A. testacea Stephens, 1830 .

They differs from the new species by the following key. 1. $7^{\text {th }}$ antennal joint distinctly longer than $6^{\text {th }}$ and $8^{\text {th }} \ldots \ldots \ldots . . .$. A.analis Erichson - $7^{\text {th }}$ antennal joint approximately equal to $6^{\text {th }}$ and $8^{\text {th }} \ldots .2$

2 . $3^{\text {rd }}$ antennal joint distinctly longer than $5^{\text {th }}$. Elytral punctation distinctly weaker than pronotal punctation .......... A.testacea Stephens - $3^{\text {rd }}$ antennal joint approximately equal to $5^{\text {th }}$. Elytral punctation equal to pronotal punctation .... A. saxonica sp.n.

From Baltic amber two species of Atomaria were described, Atomaria gedanicola Lyubarsky et Perkovsky, 2013, and Atomaria groehni Perkovsky et Lyubarsky, 2014; Eocene amber species of the genus are keyed below:

1. Pronotum broadest before the middle of its length ..... 2

- Pronotum of approximately equal width from middle to base ................................................... A saxonica sp.n.

2. Side borders of pronotum visible from above along the entire length; elytra covered by long elevated pubescence A. groehni Perkovsky et Lyubarsky

- Side borders of pronotum not visible from above along the entire length; elytra covered by decumbent pubescence A. gedanicola Lyubarsky et Perkovsky

\section{Several notes on Miocene and Cretaceous Cryptophagidae}

Miocene Epoch. The fauna of fossil Cryptophagidae belonging to the Cenozoic Era consists of extant genera. Found in the Eocene are Antherophagus Dejean, 1821, Cryptophagus Herbst, 1792, Micrambe Thomson, 1863, and Atomaria Stephens, 1829. However, two extinct genera from China were described from the Miocene diatomite from Shanwang Village, Linqu County, Shandong Province [Zhang, 1989]. These genera, Elytrophagus Zhang, 1989 and Plastophagus Zhang, 1989, have no analogues in the modern fauna and probably do not belong to Cryptophagidae. 

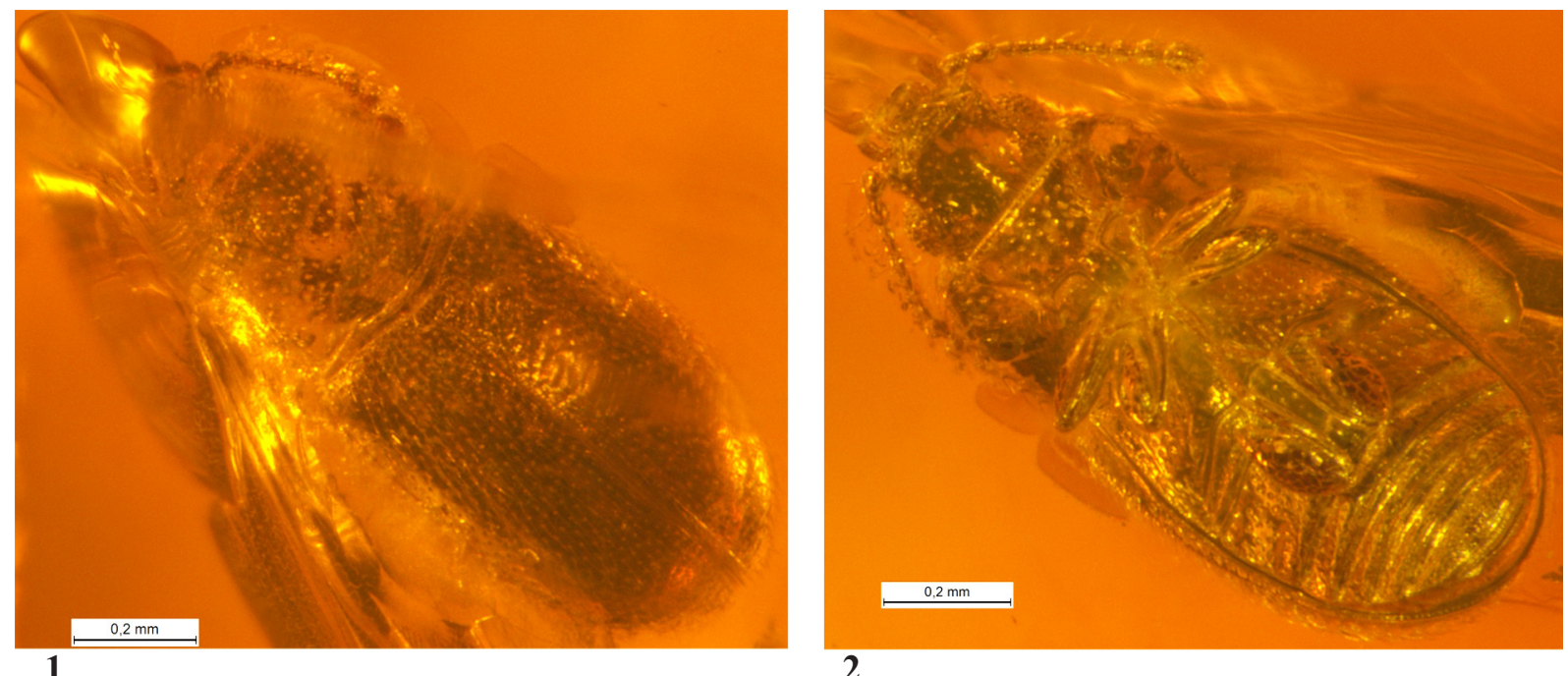

1

2

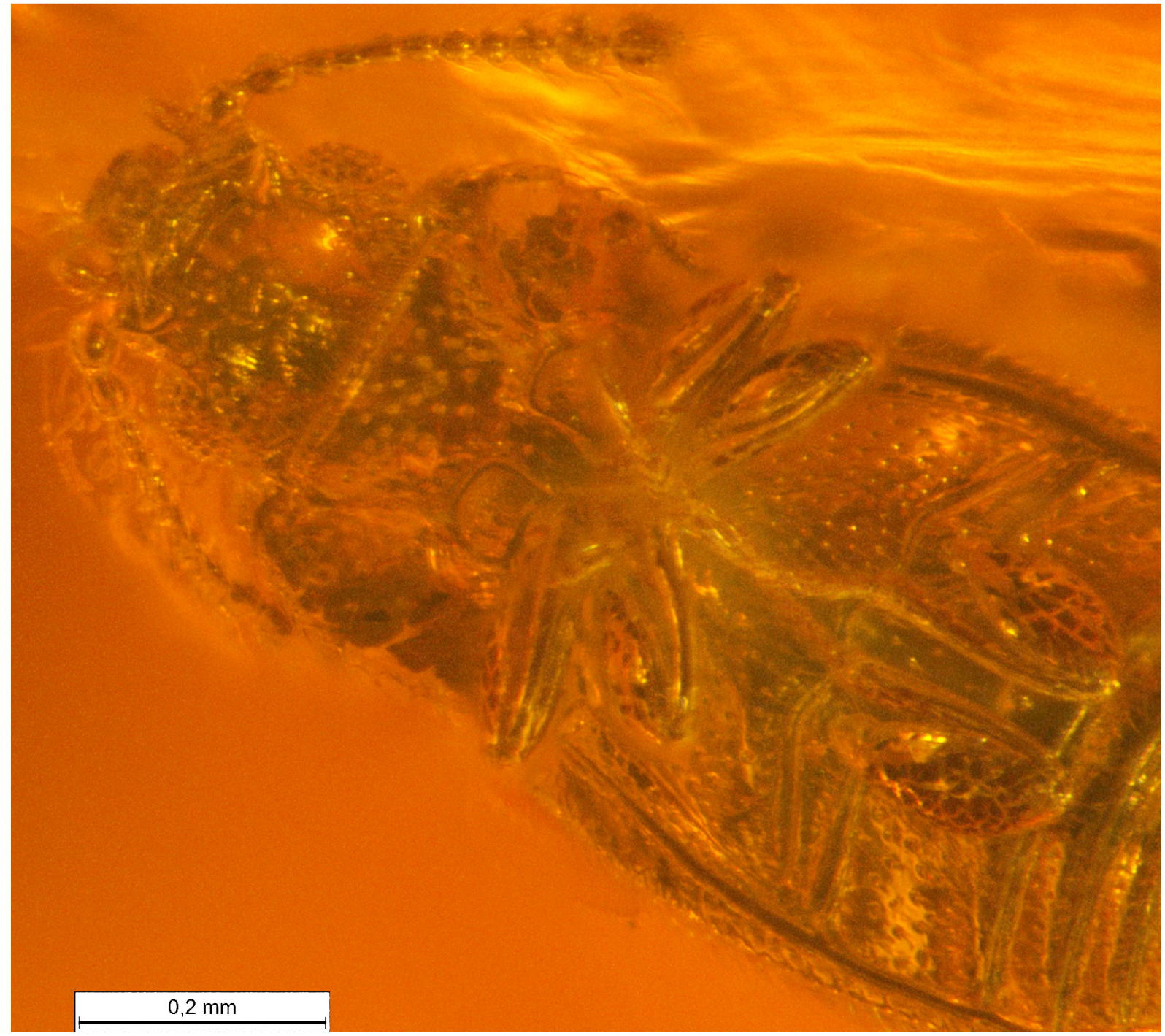

3

Figs 1-3. Photo of Atomaria saxonica sp.n.: 1 - habitus, dorsal view; 2 - habitus, ventral view; 3 - head and prosternum, ventral view.

Рис. 1-3. Фотография Atomaria saxonica sp.n.: 1 - сверху; 2 - снизу; 3 - голова и переднегрудь, снизу. 


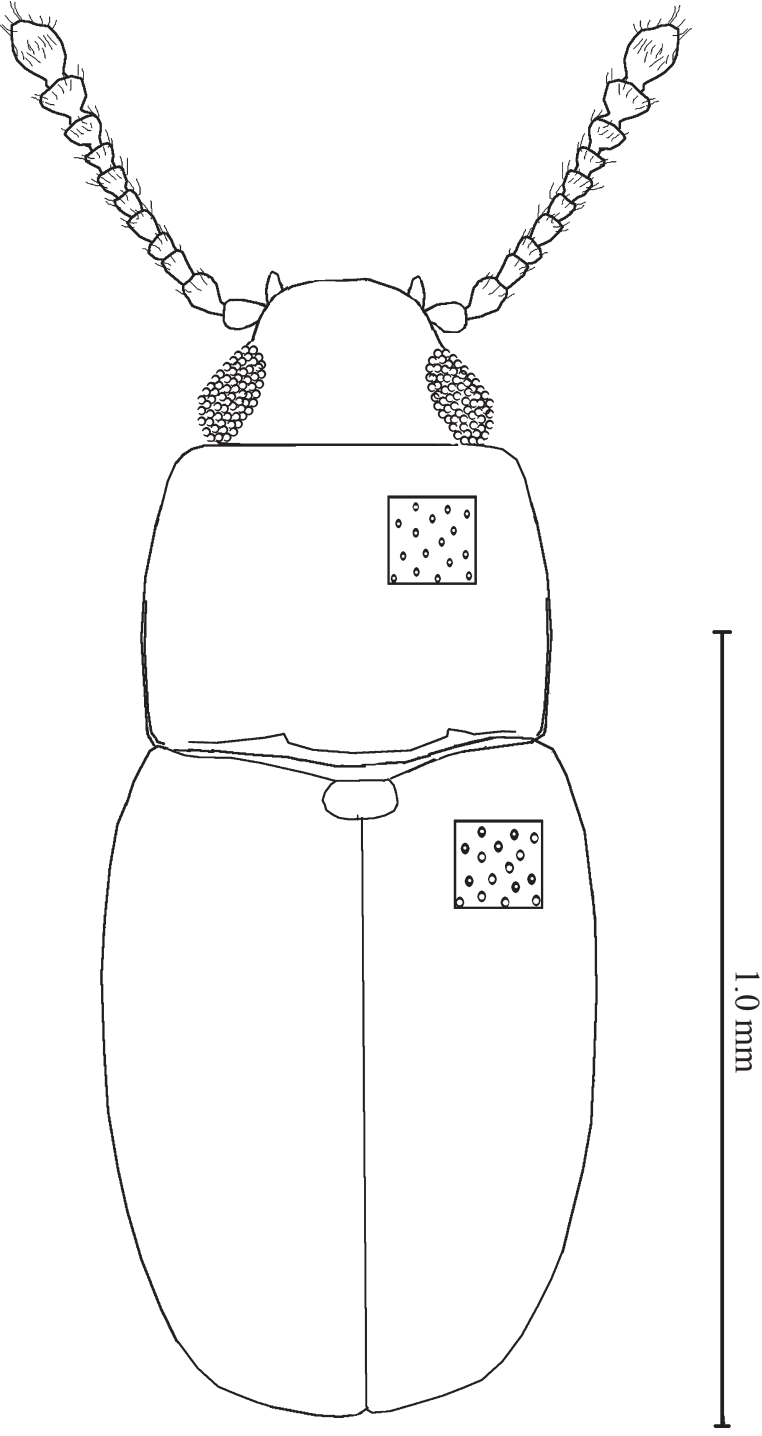

Fig. 4. Drawing of general view of Atomaria saxonica sp.n. Рис. 4. Общий вид Atomaria saxonica sp.n. (рисунок)

\section{Elytrophagus Zhang, 1989}

Type species: Elytrophagus porphyroleucus Zhang, 1989.

From extant Cryptophagidae this species distinguishes in several characters. The extant Cryptophagidae have a maximum body length up to $5.2 \mathrm{~mm}$ (Antherophagus). Elytrophagus porphyroleucus has body length $6.7 \mathrm{~mm}$. In the description it is indicated that there is a three-segmented club of antenna. However, in the photography and the drawing, four segments of the club of antenna are visible. Among the Cryptophagidae there are no antennae of this type, with a 4segment antennal club. Occasionally, a club of antenna may consist of 1 segment, or of 2, usually of 3 , but never of 4 . Elytra of Elytrophagus are covered by 8 rows of punctures. Almost all Cryptophagidae have a confused punctation in the elytra. Punctate stria on elytron are present in Henotiderus Reitter, 1877 and Striatocryptus Leschen, 1996 only, but Elytrophagus completely different from these genera.

Probably, Elytrophagus Zhang belongs to Tenebrionidae. Antennae of Elytrophagus are short, 11-jointed with indistinctly 4-jointed club. A characteristic morphological character distinguishing Tenebrionidae is that the forehead of the frons is expanded in the form of a "peak" and covers the base of the antennae. Femora in Elytrophagus are stout. $1^{\text {st }}$ ventrite is the same length as other ventrites while Cryptophagidae always have 1 ventrite longer than any other.

We conclude that Elytrophagus Zhang, 1989 does not belong to Cryptophagidae.

\section{Plastophagus Zhang, 1989}

Type species: Plastophagus pellous Zhang, 1989

Strongly different from all extant Cryptophagidae. Plastophagus pellous have body length $13.2 \mathrm{~mm}$. Antennae thick, elongated, containing 11 segments, without club or with only indistinct club. Longest is $3^{\text {rd }}$ joint of antenna; $11^{\text {th }}$ joint small. In Cryptophagidae $3^{\text {rd }}$ antennomere is slightly smaller than, or equal in length to, the $2^{\text {nd }}$ antennomere. In Cryptophagidae the last segment of the antennae may be subequal to penultimate antennomere or $2 \mathrm{x}$ the length of the penultimate antennomere, but not less than penultimate antennomere. In Plastophagus, hind femora are stout. $1^{\text {st }}$ ventrite is slightly longer than other ventrites, while in Cryptophagidae the first ventrite is usually twice as long as the following ones.

Probably, Plastophagus Zhang, 1989 does belong to Cryptophagidae either. Body size is very large. Antennae of Plastophagus are very thick, without a distinct club. There are differences in the structure of the first ventrite. Probably, Plastophagus belongs to Cleridae, and is closest to Mathesius Kolibáč et Huang, 2011.

Mesozoic Era. Thus, the Cenozoic fauna of cryptophagids consists entirely of extant genera, and we are well aware of the appearance of the beetles of this fauna. Completely different is the situation with the Mesozoic fauna. Until recently, there were almost no Mesozoic findings of cryptophagids, but now we have a general picture of this fauna. The second Lower Cretaceous genus is established below.

Family Cryptophagidae Kirby, 1837

Subfamily Atomariinae LeConte, 1861 Genus Shixitomaria gen.n.

Type species: Atomaria cretacea Cai et Wang, 2013.

The specimen was collected from the Lower Cretaceous (Aptian-Albian) Shixi Formation [Hu et al., 2017] at a locality near Qingxi, Shangrao City, Jiangxi Province of southern China.

DESCRIPTION. Body elongate, narrow, length $2.6 \mathrm{~mm}$. Eyes large, hemispherical. Head slightly narrower than prothoracic width. Frons without tubercle. Antenna relatively long, nearly reaching the posterior margin of the pronotum, with 3 -segmented club. Antennomere 1 is dilated and is the longest and widest. Antennal insertions are visibly close, the distance between them being shorter than their distance from the eyes. Antennal inserted into anterior margin of head. Antennal grooves are absent. A frontoclypeal suture is clearly present and slightly curved. Gular sutures are absent.

The pronotum is parallel-sided, its greatest width nearly at the middle, $0.54 \mathrm{~mm}$ long and $0.69 \mathrm{~mm}$ wide. The anterior pronotal margin is nearly straight. The lateral pronotal margin is present and smooth, not dentate. The prosternum apparently lacks parallel lines. Prosternum before coxae long, anterior part of prosternum (seen before coxae) twice as long as prosternal process. The procoxae are moderately separated. 
The elytra are elongate, covering the whole abdomen. The elytral epipleuron gradually narrows, is incomplete, and its ends are nearly positioned at the level of the metacoxae. The mesoventrite is not divided by a longitudinal groove. The mesocoxal cavities are moderately separated. Metacoxae are narrowly separated and do not extend laterally to meet the elytra.

The abdomen is five-segmented, gradually tapered to the apex; ventrites are apparently free. Abdominal ventrite 1 is a bit longer than any of the remaining ventrites.

DIFFERENTIAL DIAGNOSIS. Shixitomaria gen.n. belongs to Cryptophagidae: antenna with 11 antennomeres, with 3-jointed club; epipleura incomplete, reaching the level of metacoxae; abdominal ventrite 1 longer than each of the remaining ventrites.

Shixitomaria gen.n. differs from Atomaria: 1) Eye large, exceeding the length of 1 antennal segment; 2) The antennae are inserted on the anterior margin of the head, on the apex of the forehead (in extant Atomariinae and Cryptophaginae the antennae are inserted under the lateral edge of the forehead or in the middle of the forehead); 3) Boss on front of head absent (in Atomaria the boss present); 4) The anterior part of prosternum is twice as long as the prosternal process (in Atomar$i a$, anterior part of prosternum is $1-1.5 \mathrm{x}$ the length of the prosternal process); 5) $1^{\text {st }}$ ventrite a little longer than any other ventrites (in Atomaria, $1^{\text {st }}$ abdominal segment is usually as long as the two following ones taken together).

In Cai \& Wang [2013], the type species it is placed in the extant Atomariinae based on the presence of a distinct frontoclypeal suture. However, the length of prosternal process and anterior part of prothorax are not typical for the tribe Atomariini, nor the length of the first ventrite. From the tribe Cryptafricini this species is different in body shape, and from the tribe Hypocoprini in frontoclypeal suture present. Judging by frontoclypeal suture, it belongs to Atomariini, but there are some characters of Hypocoprini as well. For the time being it should be attributed to the tribe Atomariini.

Thus, the Mesozoic fauna includes five genera of Cryptophagidae: three genera of Cryptophaginae: Albocryptophagus Peris, Lyubarsky et Perkovsky, 2017 (1 extinct species, Albian Spanish amber); Microticus Lyubarsky, Perkovsky, 2015 (1 extinct species, Santonian Taimyr amber); Ennoticus Lyubarsky et Perkovsky, 2017 (1 extinct species, Santonian Taimyr amber) [Peris et al., 2017; Lyubarsky, Perkovsky, 2017a]; and two genera of Atomariinae: Nganasania Zherikhin, 1977 [Lyubarsky, Perkovsky, 2014, 2017b: 2 extinct species, Santonian Taimyr amber]; Shixitomaria gen.n. (1 extinct species, Aptian-Albian, Jiangxi, China). All 5 genera occur only in the Aptian-Santonian. From the Cenozoic fauna the fauna of the Mesozoic differs by a complete change in the composition of genera.

ACKNOWLEDGEMENTS. We are grateful to Christel and Hans Werner Hoffeins (Hamburg, Germany) for providing the material, to Vitaly Yu. Nazarenko (Schmalhausen Institute of Zoology, Kiev, Ukraine) for kindly taking photographs of the specimen, to Alexandr P. Rasnitsyn (Palaeontological Institute, Moscow) for valuable discussion of the paper. The work of the first author has been supported by the grant AAAA-A16-116021660077-3.

\section{References}

Bukejs A., Biondi M., Alekseev V.I. 2016. New records and species of Crepidodera Chevrolat (Coleoptera: Chrysomelidae) in Eocene European amber, with a brief review of described fossil beetles from Bitterfeld amber // Zootaxa. Vol.4193. No.2. P.390-400. doi: $10.11646 /$ zootaxa.4193.2.13.

Cai C.-Y., Wang B. 2013. The oldest silken fungus beetle from the Early Cretaceous of southern China (Coleoptera: Cryptophagidae: Atomariinae) // Alcheringa. Vol.37. P.1-4.

Hu G., Hu W., Cao J., Yang R., Chen H., Zhao D., Pang Q., Wang H., Tan X. 2017. The distribution, hydrocarbon potential, and development of the Lower Cretaceous black shales in coastal southeastern China // Journal of Palaeogeography. Vol.6. No.4. P.333-351. doi: 10.1016/j.jop.2017.08.002.

Johnson C., Otero J.C., Leschen R.A.B. 2007. Family Cryptophagidae // I. Löbl., A. Smetana (eds.). A catalogue of Palaearctic Coleoptera. Vol.4. Steenstrup: Apollo Books. P.513-531.

Leschen R.A.B. 1996. Phylogeny and revision of the genera of Cryptophagidae (Coleoptera: Cucujoidea) // The University of Kansas Science Bulletin. Vol.55. No.15. P.549-634.

Lyubarsky G.Yu., Perkovsky E.E. 2010. First Eocene species of the genus Micrambe (Cryptophagidae: Coleoptera, Clavicornia) // Vestnik zoologii. Vol.44. No.3. P.275-279.

Lyubarsky G.Yu., Perkovsky E.E. 2011. Third contribution on Rovno amber silken fungus beetles: a new Eocene species of Cryptophagus (Coleoptera, Clavicornia, Cryptophagidae) // ZooKeys. Vol.130. P.255-261.

Lyubarsky G.Yu., Perkovsky E.E. 2012. The first Eocene species of the genus Cryptophagus (Coleoptera, Clavicornia, Cryptophagidae) // Vestnik zoologii. Vol.46. No.1. P.83-87.

Lyubarsky G.Yu., Perkovsky E.E. 2013. Fourth contribution on late Eocene amber silken fungus beetles: a new Baltic amber species of Atomaria (Coleoptera, Clavicornia, Cryptophagidae) // Vestnik zoologii. Vol.47. No.3. P.273-276.

Lyubarsky G.Yu., Perkovsky E.E. 2014. New species of the genus Nganasania from Upper Cretaceous of Taymyr (Coleoptera, Cryptophagidae) // Russian Entomological Journal. Vol.23. No.3. P.191-194

Lyubarsky G.Yu., Perkovsky E.E. 2017a. [New genus Ennoticus from the Upper Cretaceous of Taimyr (Coleoptera: Cryptophagidae)] // Paleontologicheskii Zhurnal. No.2. P.81-85. [in Russian, English translation: Paleontological Journal. Vol.51. No.2. P.191-195].

Lyubarsky G.Yu., Perkovsky E.E., 2017b. Re-description of the genus Nganasania Zherikhin from Upper Cretaceous of Taimyr (Coleoptera: Cryptophagidae) // Russian Entomological Journal. Vol.26. No.3. P.251-255.

Peris D., Lyubarsky G.Yu., Perkovsky E.E. 2017. A new genus of silken-fungus beetle (Coleoptera: Cryptophagidae) from the Spanish Cretaceous amber // Cretaceous Research. Vol.78. P.191-195.

Perkovsky E.E., Lyubarsky G.Yu. 2014. Fifth contribution on silken fungus beetles from Late Eocene amber: a second Baltic amber species of Atomaria (Coleoptera: Clavicornia: Cryptophagidae) // Russian Entomological Journal. Vol.23. No.1. P.41-44.

Zhang J.-F. 1989. Fossil Insects from Shanwang, Shandong, China. Jinan: Shandong Science and Technology Publishing House. 459 p. 